\title{
Dolichol phosphate mannose synthase (DPM1) mutations define congenital disorder of glycosylation Ie (CDG-Ie)
}

\author{
Soohyun Kim, ${ }^{1}$ Vibeke Westphal, ${ }^{1}$ Geetha Srikrishna, ${ }^{1}$ Darshini P. Mehta, ${ }^{1}$ \\ Sandra Peterson, ${ }^{1}$ James Filiano, ${ }^{2}$ Pamela S. Karnes, ${ }^{3}$ Marc C. Patterson, ${ }^{3}$ \\ and Hudson H. Freeze ${ }^{1}$
}

${ }^{1}$ The Burnham Institute, La Jolla, California 92037, USA
${ }^{2}$ Dartmouth-Hitchcock Medical Center, Lebanon, New Hampshire 03756, USA
${ }^{3}$ Mayo Clinic and Foundation, Rochester, Minnesota 55905, USA

Address correspondence to: Hudson H. Freeze, The Burnham Institute, 10901 North Torrey Pines Road, La Jolla, California 92037, USA. Phone: (858) 646-3142; Fax: (858) 646-3193; E-mail: hudson@burnham.org.

Soohyn Kim's present address is: Korea Basic Science Institute, Taejon 305-333, South Korea.

Soohyun Kim and Vibeke Westphal contributed equally to this work.

Received for publication May 10, 1999, and accepted in revised form December 8, 1999.

Congenital disorders of glycosylation (CDGs) are metabolic deficiencies in glycoprotein biosynthesis that usually cause severe mental and psychomotor retardation. Different forms of CDGs can be recognized by altered isoelectric focusing (IEF) patterns of serum transferrin (Tf). Two patients with these symptoms and similar abnormal Tf IEF patterns were analyzed by metabolic labeling of fibroblasts with $\left[2-{ }^{3} \mathrm{H}\right]$ mannose. The patients produced a truncated dolichol-linked precursor oligosaccharide with 5 mannose residues, instead of the normal precursor with 9 mannose residues. Addition of 250 $\mu \mathrm{M}$ mannose to the culture medium corrected the size of the truncated oligosaccharide. Microsomes from fibroblasts of these patients were approximately $95 \%$ deficient in dolichol-phosphate-mannose (Dol-P-Man) synthase activity, with an apparent $\mathrm{K}_{\mathrm{m}}$ for GDP-Man $\sim 6$-fold higher than normal. DPM1, the gene coding for the catalytic subunit of Dol-P-Man synthase, was altered in both patients. One patient had a point mutation, $\mathrm{C}_{274} \mathrm{G}$, causing an $\mathrm{R}_{92} \mathrm{G}$ change in the coding sequence. The other patient also had the $\mathrm{C}_{274} \mathrm{G}$ mutation and a 13-bp deletion that presumably resulted in an unstable transcript. Defects in DPM1 define a new glycosylation disorder, CDG-Ie.

J. Clin. Invest. 105:191-198 (2000).

\section{Introduction}

Patients with congenital disorders of glycosylation (CDGs) have defects in protein glycosylation that cause multisystemic abnormalities, which usually include mental and psychomotor retardation, peripheral neuropathy, coagulopathy, and retinitis pigmentosa (1-3). Most known patients are deficient in phosphomannomutase (PMM; Man-6-P $\rightarrow$ Man-1-P), which is required for the synthesis of GDP-Man used in protein glycosylation $(4,5)$. Other patients with CDG have normal mental and psychomotor development but suffer from hypoglycemia, coagulopathy, severe vomiting, diarrhea, and congenital hepatic fibrosis (6-8). These patients are deficient in phosphomannose isomerase (PMI; Fru-6-P $\rightarrow$ Man-6-P), a key enzyme used in 1 of the 2 known routes for Man-6-P synthesis. The other route is the direct import and conversion of mannose into Man-6-P via a kinase. Dietary supplements of mannose can provide sufficient Man-6-P to patients with CDG who are PMI deficient and can relieve most or all of their symptoms (6).

Suspected cases of CDG are confirmed by serum transferrin (Tf) isoelectric focusing (IEF) analysis that detects changes in the sialic acid content of the sugar chains (9) that result from the absence of entire sugar chains or from changes in their structure (10-14). Various Tf IEF patterns are pathognomic of misglycosylation, but they do not indicate the defect (1). For instance, deficiencies in PMM (CDG-Ia) and PMI (CDG-Ib) generate the same Tf IEF pattern. Another abnormal IEF pattern was found in 2 cases showing practically no psychomotor development, reduced responsiveness, intractable epileptic seizures, and hypotonia (15). Here, we analyze 2 other patients with Tf IEF patterns and symptoms similar to those cases (15). Dolichol-phosphate-mannose (Dol-P-Man) synthesis is defective in these patients and mutations in DPM1, the catalytic subunit of Dol-P-Man synthase, presumably cause their altered glycosylation. These cellular glycosylation defects were corrected by adding mannose to the culture medium.

\section{Methods}

Materials. Most of the materials were obtained from Sigma Chemical Co. (St. Louis, Missouri, USA), except for the following: anti-transferrin (DAKO Corp., Capinteria, California, USA) ampholytes ( $\mathrm{pH}$ 5-7) (BioRad Laboratories Inc., Hercules, California, USA), Concanavalin A (Con A)-Sepharose (Pharmacia Fine Chemicals, Piscataway, New Jersey, USA), MEM ( $\alpha$ - 
MEM and DMEM; GIBCO BRL, Life Technologies, Gaithersburg, Maryland, USA), RPMI 1604 medium (Irvine Scientific, La Jolla, California, USA), FBS (Hyclone Laboratories, Logan, Utah), Microsorb-MV $\mathrm{NH}_{2}$ HPLC column (Varian Instruments, Walnut Creek, California, USA), and Microcon-10 filters (Amicon, Inc., Beverly, Massachusetts, USA). Fluorescently labeled (2-aminobenzamide [2-AB]) oligosaccharides, $\mathrm{Man}_{5} \mathrm{GlcNAc}_{2}$ and $\mathrm{Man}_{9} \mathrm{GlcNAc}_{2}$, were purchased from Glyko, Inc. (Novato, California, USA).

Radiolabels. $\left[2-{ }^{3} \mathrm{H}\right]$ Mannose $(20 \mathrm{Ci} / \mathrm{mmol})$, UDP$\left[{ }^{3} \mathrm{H}\right]$ glucose $(60 \mathrm{Ci} / \mathrm{mmol})$, and GDP-[ $\left[{ }^{3} \mathrm{H}\right]$ mannose $(10$ $\mathrm{Ci} / \mathrm{mmol}$ ) were from American Radiolabeled Chemicals, Inc. (St. Louis, Missouri, USA). Tran ${ }^{35}$ S-label $(1,000 \mathrm{Ci} / \mathrm{mmol})$ was obtained from ICN Pharmaceuticals, Inc. (Costa Mesa, California, USA).

Cell lines and sera. Fibroblasts from a $\alpha 1,3$-glucosyltransferase-deficient, CDG-Ic, patient were obtained from Simon Murch, Royal Free Hospital, London. Normal control fibroblasts were obtained from Advanced Tissue Sciences (La Jolla, California, USA). Fibroblasts were grown in a $\alpha$-MEM containing $10 \%$ heat-inactivated FBS and $2 \mathrm{mM}$ glutamine. Lymphoblasts were grown in RPMI 1640 medium supplemented with 15\% heat-inactivated FBS and $2 \mathrm{mM}$ glutamine. Leukocytes from patients and healthy volunteers were obtained immediately after blood draw using dextran sedimentation as described previously (16).

IEF of Tf. Serum $(100 \mu \mathrm{L})$ was iron saturated at room temperature for 1 hour with $5 \mu \mathrm{L}$ of $0.5 \mathrm{M} \mathrm{NaHCO}_{3}$ and $5 \mu \mathrm{L}$ of $20 \mathrm{mM} \mathrm{FeCl}_{3}$. One microliter of 10-fold-diluted serum was spotted on polyacrylamide gels $(\mathrm{T}=5 \%, \mathrm{C}=3 \%)$ containing 5\% ampholytes ( $\mathrm{pH} 5-7$ ). After electrophoresis, the gel was covered with $80 \mu \mathrm{L}$ of anti-transferrin for 15 minutes at $22^{\circ} \mathrm{C}$. The gel was washed overnight with physiological saline, stained with Coomassie Brilliant Blue, destained, dried, and photographed (6).

PMI and PMM assays. PMI and PMM assays were carried out as previously described, except $10 \mu \mathrm{M}$ glucose1,6-bisphosphate was used for the PMM assays (6).

Labeling with $\left[2-{ }^{-3} \mathrm{H}\right]$ mannose. Fibroblasts at $70-80 \%$ confluency were labeled with $\left[2-{ }^{3} \mathrm{H}\right]$ mannose $(10 \mu \mathrm{Ci} / \mathrm{mL})$ and $\operatorname{Tran}{ }^{35} \mathrm{~S}$-label $(2 \mu \mathrm{Ci} / \mathrm{mL})$ for 60 minutes in DMEM containing $0.5 \mathrm{mM}$ glucose and $2 \mathrm{mM}$ glutamine. Medium was removed, and cells were washed with ice-cold PBS, trypsinized, washed again, solubilized in $0.2 \%$ SDS, and counted. The lysate was used for protein determination and analyzed with and without digestion using endoglycosidase $\mathrm{H}$ (Endo H). Labeled macromolecules were quantified by binding to nitrocellulose (17).

Analysis of $\left[2-{ }^{3} \mathrm{H}\right]$ mannose-labeled Dol-P-Man and lipidlinked oligosaccharide. Dol-P-Man and lipid-linked oligosaccharide (LLO) isolation were described previously (18). Dol-P-[2- $\left.{ }^{3} \mathrm{H}\right]$ Man identity was confirmed by thin layer chromatography (TLC) on silica gel 60 plate (Whatman International Ltd., Kent, United Kingdom) developed in chloroform/methanol/water (10:10:3). Oligosaccharides from the LLO were released by mild acid hydrolysis (18), dried, resuspended in 50\% ace- tonitrile, and analyzed by HPLC on a Rainin Microsorb-MV $(250 \times 4.6 \mathrm{~mm}$; $5 \mu \mathrm{m}$; Walnut Creek, California, USA) column eluted with $70-45 \%$ linear gradient of acetonitrile for 75 minutes at a flow rate of $0.5 \mathrm{~mL} / \mathrm{min}$. Internal standards of 2-AB-labeled fluorescent oligosaccharides $\left(\mathrm{Man}_{5} \mathrm{GlcNAc}_{2}\right.$ and Man ${ }_{9} \mathrm{Glc}-$ $\mathrm{NAc}_{2}$ ) were included in each run and monitored with an inline fluorescence detector, and ${ }^{3} \mathrm{H}$-labeled oligosaccharides were counted on a $\beta$-RAM flow detector (IN/US Systems, Tampa, Florida, USA).

Analysis of $\left[2{ }^{-3} \mathrm{H}\right]$ mannose-labeled oligosaccharides from glycoproteins. Fibroblasts (70-80\% confluence) were labeled with $50 \mu \mathrm{Ci} / \mathrm{mL}\left[2-{ }^{3} \mathrm{H}\right]$ mannose for 24 hours in $\alpha \mathrm{MEM}$ with $5 \mathrm{mM}$ glucose and 5\% FBS. Cells were sonicated in PBS containing protease inhibitors, $1 \%$ NP40, and then centrifuged at $14,000 \mathrm{~g}$ for 30 minutes, followed by ultrafiltration through YM10 membranes (Amicon, Bedford, Massachusetts, USA) to remove low-molecular weight molecules. More than $90 \%$ of the label in the retained fraction was trichloroacetic acid precipitable. PNGase F digestion (18) released $N$-linked oligosaccharides that were recovered as a YM10 membrane filtrate. Labeled oligosaccharides in $0.2 \mathrm{~mL}$ were applied to $0.3 \mathrm{~mL}$ of ConA-Sepharose column in $10 \mathrm{mM}$ Tris ( $\mathrm{pH}$ 7.5) containing $0.15 \mathrm{M} \mathrm{NaCl}, 1 \mathrm{mM} \mathrm{MgCl}_{2}$, and $1 \mathrm{mM} \mathrm{CaCl}_{2}$, washed with $4 \times 1.5 \mathrm{~mL}$ of the same buffer, and sequentially eluted with $10 \mathrm{mM} \alpha$-methyl glucoside, $10 \mathrm{mM} \alpha$ methyl mannoside, and $100 \mathrm{mM} \alpha$-methyl mannoside as described elsewhere $(17,18)$. PNGase F-released oligosaccharides were analyzed by HPLC using the same conditions used for analysis of LLO.

Dol-P-Man synthase assay. Cells were sonicated in $10 \mathrm{mM}$ Tris ( $\mathrm{pH} 7.5), 0.25 \mathrm{M}$ sucrose, and protease inhibitor cocktail (Boehringer Mannheim, Indianapolis, Indiana, USA) on ice and centrifuged at $1,000 \mathrm{~g}$ for 10 minutes. Microsomal membranes were defined as a $105,000 \mathrm{~g} \times 1$ hour pellet. Dolichol-P ( $5 \mu \mathrm{g}$; Sigma Chemical Co.) was dried under nitrogen and dissolved in $100 \mathrm{mM}$ Tris- $\mathrm{HCl}(\mathrm{pH}$ 8.0), $0.4 \%$ Triton-X-100, $0.7 \% \beta$-mercaptoethanol, $5 \mathrm{mM}$ $\mathrm{MgCl}_{2}, 1 \mathrm{mM}$ EDTA, and $0.2 \mu \mathrm{M}$ GDP-[$\left[{ }^{3} \mathrm{H}\right]$ mannose (American Radiolabeled Chemicals) with various amount of cold GDP-mannose (Sigma Chemical Co.). Microsomal membranes $(20 \mu \mathrm{g})$ were added to give a final volume of $50 \mu \mathrm{L}$. The mixture was incubated for 15 minutes at $37^{\circ} \mathrm{C}$, and the Dol-P-Man was extracted by adding $0.2 \mathrm{~mL}$ $4 \mathrm{mM} \mathrm{MgCl}_{2}$ and $1 \mathrm{~mL}$ chloroform/methanol (3:2). The upper phase was discarded after centrifugation. The lower phase was washed twice with $1 \mathrm{~mL}$ of chloroform/methanol/water/0.1 $\mathrm{M} \mathrm{MgCl}_{2}(3: 48: 47: 2)$, transferred to a scintillation vial, and dried, and scintillation cocktail was added for counting. Apparent $\mathrm{K}_{\mathrm{m}}$ for GDPMan was calculated using $0.2-100 \mu \mathrm{M}$ substrate. Routine assays used $10 \mu \mathrm{M}$ GDP-Man. Dol-P-Glc synthase assays used the same conditions and UDP- $\left[{ }^{3} \mathrm{H}\right] \mathrm{glucose}(10 \mu \mathrm{M}$, $0.1 \mu \mathrm{Ci}$; American Radiolabeled Chemicals) donor.

RT-PCR and sequencing the DPM1, DPM2, DPM3, and $S L 35$ cDNA. Fibroblasts grown in $\alpha$-MEM (GIBCO BRL, Life Technologies) to $70-80 \%$ confluence were harvested by trypsinization, and the RNA was purified 
using Trizol reagent (GIBCO BRL, Life Technologies). RT-PCR was performed using Superscript One-Step RT-PCR System (GIBCO BRL, Life Technologies) with total RNA as template. For the DPM1 gene oVW100: $5^{\prime}$ CCG CGC CAC ATT ACG 3' and oVW125: 5' GGT GGT CTT CAT AAA AAG $3^{\prime}$ were used as primers in the following RT-PCR reaction: $45^{\circ} \mathrm{C}$ for 40 minutes; $94^{\circ} \mathrm{C}$ for 2 minutes; $50 \times 94^{\circ} \mathrm{C}$ for 20 seconds, $46^{\circ} \mathrm{C}$ for 30 seconds, $70^{\circ} \mathrm{C}$ for 1 minute; and $70^{\circ} \mathrm{C}$ for 10 minutes. For the DPM2 gene oVW127: 5' CGG GTG GCT GAG CGC GCG 3' and oVW128: 5' CCT GCG GGA CCT TCA CTG AGC $3^{\prime}$ were used as primers. The conditions were $50^{\circ} \mathrm{C}$ for 30 minutes; $94^{\circ} \mathrm{C}$ for 2 minutes; $30 \times$ $94^{\circ} \mathrm{C}$ for 20 seconds, $50^{\circ} \mathrm{C}$ for 30 seconds, $70^{\circ} \mathrm{C}$ for 1 minute; and $70^{\circ} \mathrm{C}$ for 10 minutes. For the DPM3 gene oVW150: 5’ GGT GGG GTA GAG TGA CCA TGA 3' and oVW151: 5' GGA ATG GGG TTA GGC TGT CAG $3^{\prime}$ were used. The RT-PCR conditions were: $48^{\circ} \mathrm{C}$ for 30 minutes; $94^{\circ} \mathrm{C}$ for 2 minutes; $35 \times 94^{\circ} \mathrm{C}$ for 20 seconds, $50^{\circ} \mathrm{C}$ for 30 seconds, $70^{\circ} \mathrm{C}$ for 40 seconds; and $70^{\circ} \mathrm{C}$ for 7 minutes. For the SL35 gene oVW134: 5' GAG CTA GCT TTG CAA TAT G $3^{\prime}$ and oVW137: AGC AGG CTG GCT CAG ATG GGG 3' were used in the following reaction: $50^{\circ} \mathrm{C}$ for 40 minutes; $94^{\circ} \mathrm{C}$ for 2 minutes; $40 \times 94^{\circ} \mathrm{C}$ for 20 seconds, $55^{\circ} \mathrm{C}$ for 30 seconds, $70^{\circ} \mathrm{C}$ for 1 minute; and $70^{\circ} \mathrm{C}$ for 10 minutes. The products were analyzed on a $0.8 \%$ agarose gel and purified from gel using the QIAquick Gel Extraction Kit (Qiagen Inc., Valencia, California, USA). Sequencing reactions were done with appropriate primers and the Big Dye sequencing kit (Perkin Elmer Corp., Norwalk, Connecticut, USA), precipitation with ethanol, and subsequent analysis on an ABI 377 DNA sequencer. Three different RNA preparations of each were analyzed.

Sequencing of the exon 4 of DPM1. The sequence of the exon 4 and 5 of DPM1 was kindly provided by $\mathrm{E}$. Schollen and G. Matthijs (Center for Human Genetics, Leuven, Belgium). Oligonucleotides oVW152 AAT GTG TGC TCT TCA GGT GCT and oVW153: 5' TGA AAA TAA GCC CAA AAC CA 3' were used in a standard PCR reaction with purified genomic DNA from leukocytes and fibroblasts as a template: $94^{\circ} \mathrm{C}$ for 2 minutes; $30 \times 94^{\circ} \mathrm{C}$ for 20 seconds, $50^{\circ} \mathrm{C}$ for $30 \mathrm{sec}-$ onds, $70^{\circ} \mathrm{C}$ for 45 seconds; $70^{\circ} \mathrm{C}$ for 7 minutes. Sequence reactions were carried out as already described here.

Semiquantitative RT-PCR. Between 0.1 and $1.0 \mu \mathrm{g}$ total RNA were used for the semiquantitative RTPCR. Oligonucleotides for amplifying the respective genes were oVW124 and oVW125 for DPM1, oVW127 and 128 for DPM2, and LHPMI5-25: 5' CAT GGC CGC TCC GCG AGT ATT $3^{\prime}$ and LHPMI1348-1362: 5' TCC AGA GCA AGG AAG 3' for the PMI1 gene. Because of different annealing temperatures of the oligonucleotides and differences in the abundance of the various mRNAs, multiple conditions were used for RT-PCR reactions. Conditions for the DPM1 gene were as follows: $45^{\circ} \mathrm{C}$ for 40 minutes; $94^{\circ} \mathrm{C}$ for 2 minutes; $40 \times 94^{\circ} \mathrm{C}$ for 20 seconds, $46^{\circ} \mathrm{C}$ for 30 seconds, $70^{\circ} \mathrm{C}$ for 1 minute; and $70^{\circ} \mathrm{C}$ for 10 minutes. Conditions for the DPM2 gene were as follows: $50^{\circ} \mathrm{C}$ for 30 minutes; $94^{\circ} \mathrm{C}$ for 2 minutes; $27 \times 94^{\circ} \mathrm{C}$ for 20 seconds, $50^{\circ} \mathrm{C}$ for 30 seconds, $70^{\circ} \mathrm{C}$ for 45 seconds; and $70^{\circ} \mathrm{C}$ for 5 minutes. Conditions for the PMI1 gene were as follows: $46^{\circ} \mathrm{C}$ for 40 minutes; $94^{\circ} \mathrm{C}$ for 2 minutes; $27 \times 94^{\circ} \mathrm{C}$ for 20 seconds, $48^{\circ} \mathrm{C}$ for 30 seconds, $70^{\circ} \mathrm{C}$ for 1 minute for 30 seconds; and $70^{\circ} \mathrm{C}$ for 10 minutes.

\section{Results}

Clinical presentation. Clinical summaries of the patients are presented in Table 1. PY was born to a gravida 14, para 3, SAB (spontaneous abortions) 11 mother. The postnatal course was complicated by hydrops, respiratory distress, apnea, patent ductus arteriosus, and transient hypertension. At 80 weeks' post-conceptional age, the infant developed generalized medically intractable seizures. He has low antithrombin III, protein $\mathrm{C}$, and protein S, along with elevated levels of liver enzymes and creatine kinase. Karyotype was normal. At 3 years, the child has no speech, is cortically blind, has strabismus, and poor swallowing. He remains profoundly hypotonic and has frequent seizures. His height and weight remain below the fifth percentile despite caloric supplementation.

Patient $\mathrm{CH}$ (born to a gravida 3, para 2, SAB 1 mother) was seen at 10 months because of developmental delay, hypotonia, seizures, and acquired microcephaly. In the neonatal period, the infant was markedly hypotonic, and cyanotic/apneic spells were associated with an abnormal EEG. CT and MRI of her head were

\section{Table 1}

Summary of clinical and laboratory features

\begin{tabular}{|c|c|c|}
\hline & $\mathrm{CH}$ & PY \\
\hline Gestation & 41 weeks & 29 weeks \\
\hline Hypotonia & +++ & +++ \\
\hline Vision & Cortical blindness & Cortical blindness \\
\hline Strabismus & - & + \\
\hline Microcephaly & +++ & ++ \\
\hline Inverted nipples & - & + \\
\hline Facial dysmorphism & + & - \\
\hline Deep tendon reflexes & ++ & 0 \\
\hline Seizures & Medically intractable & Medically intractable \\
\hline Somatic growth & Normal (10 months) & $\begin{array}{c}\text { < P5 (height and weight) } \\
\text { (3 years) }\end{array}$ \\
\hline Antithrombin III & Low & Low \\
\hline Creatine kinase & +++ & + \\
\hline Ammonia & 0 & + \\
\hline Urine oligosaccharides & 0 & + \\
\hline Nerve conduction studies & Not done & Slowed velocities \\
\hline EEG & $\begin{array}{l}\text { Multifocal independent spikes; } \\
\text { background slowing }\end{array}$ & $\begin{array}{l}\text { Multifocal independent } \\
\text { spikes, background slowing; } \\
\text { electrographic seizures }\end{array}$ \\
\hline MRI head & Delayed myelination & $\begin{array}{c}\text { Delayed myelination, } \\
\text { hypoplastic left inferior } \\
\text { frontal lobe, cerebellar atrophy }\end{array}$ \\
\hline MR spectroscopy & Normal & Not done \\
\hline
\end{tabular}

$0=$ normal; + to +++ , present/abnormal/increased to markedly abnormal/increased; P5 = fifth percentile for age. 
Figure 1

TfIEF patterns of control and patients with CDG. Patients deficient in phosphomannomutase (PMM, CDG-la) and phosphomannose isomerase (PMI, CDG-Ib) have similar patterns. Patients $\mathrm{PY}$ and $\mathrm{CH}$ have a prominent increase in disialo transferrin compared with controls. Numbers at right indicate numbers of sialic acid residue per transferrin molecule.

reported to be normal. Height, weight, and karyotype were normal, but microcephaly $(<\mathrm{P} 5)$ was seen. The occiput and nasal bridge were flat. Palpebral fissures were downslanting, and there were telangiectasia on the eyelids and hemangiomas of the occiput and the sacrum. The palate was high and narrow. There was mild shortening of the extremities, particularly the arms. The mouth formed an inverted $\mathrm{V}$ shape, with diminished movement on crying. Tone was diffusely reduced, but deep tendon reflexes were increased, more in the lower than the upper extremities. MR spectroscopy demonstrated normal spectra in voxels in left frontoparietal white matter and right basal ganglia.

Analysis of Tf IEF, PMM, and PMI activities. Figure 1 shows the results of Tf IEF analysis from a normal control and 4 patients. Control primarily have tetrasialo Tf, whereas PMM- or PMI-deficient patients show increased di- and asialo Tf, typical of CDG-I. Patients PY and $\mathrm{CH}$ also have abnormal IEF patterns with increased disialo Tf, but very little, if any, asialo Tf. PY and $\mathrm{CH}$ have normal PMM activity ( 3.6 and $3.1 \mathrm{nmol} / \mathrm{min}$ per milligram, respectively) versus control $(3.6 \mathrm{nmol} / \mathrm{min}$ per milligram) and normal PMI activity (9.3 and 8.9 $\mathrm{nmol} / \mathrm{min}$ per milligram, respectively) versus control $(9.3 \mathrm{nmol} / \mathrm{min}$ per milligram) suggesting that another defect causes the altered Tf IEF pattern.

$\left[2-{ }^{3} \mathrm{H}\right]$ Mannose labeling of fibroblasts. Fibroblasts from patient PY and control were labeled with $\left[{ }^{3} \mathrm{H}\right]$ mannose, and the $N$-linked chains were released using PNGase F digestion. Ion-exchange chromatography of samples from both control and patient samples showed that about $30 \%$ of intracellular $\left[{ }^{3} \mathrm{H}\right]$ mannoselabel sugar chains had 1-3 charges, whereas approximately $50 \%$ of the label was anionic in secreted glycoproteins. Essentially all of the charge was sialidase sensitive (data not shown). Oligosaccharides from

Table 2

Sensitivity of $\left[2-{ }^{3} \mathrm{H}\right]$ mannose-labeled oligosaccharides to Endo $\mathrm{H}$ digestion

Endo $\mathrm{H}$-sensitivity (\%)

$\begin{array}{lcc}\text { Cell line } & - \text { Mannose } & + \text { Mannose } \\ \text { Control } & 80 & 87 \\ \text { BB } & 72 & 83 \\ \text { PY } & 37 & 66 \\ \text { CH } & 41 & 63\end{array}$

Fibroblast cultures were labeled with [2-3H] mannose for 1 hour in the presence or absence of $250 \mu \mathrm{M}$ mannose, and the glycoproteins were digested with Endo $\mathrm{H}$ and analyzed as described in the Methods. intracellular glycoproteins were fractionated by ConA-Sepharose chromatography into tri- and tetra-antennary (run-through, fraction I), biantennary $(10 \mathrm{mM} \alpha$-MeGlc, fraction II), mostly hybrid (10 $\mathrm{mM} \alpha$-MeMan, fraction III), and high mannose-type (100 mM $\alpha$-MeMan, fraction IV) chains. Compared with control, the patient showed a 2 -fold decrease in high mannose chains (fraction IV) and proportionate increases in the other fractions (Figure 2a). The altered distribution of the patient's oligosaccharides was partially corrected by adding $250 \mu \mathrm{M}$ mannose to the culture medium during labeling, but mannose had no effect on the profile of oligosaccharides from normal cells.

Each ConA-Sepharose fraction was desialated and the size of the oligosaccharides was determined by HPLC analysis. The elution profiles of fractions I, II, and IV were identical in samples from PY and control. In contrast, the majority of fraction III oligosaccharides from PY were smaller than were those of the control fraction III (see Figure 2, c and b, respectively). A prominent peak (indicated by the arrowhead) in PY corresponds to the elution position of $\mathrm{Man}_{5} \mathrm{GlcNAc}_{2}$, an LLO precursor that also elutes in fraction III (data not shown). The altered ConA-Sepharose distribution pattern suggests the patient is defective in the synthesis of high mannose-type chains.

Fibroblasts from control and from PY and $\mathrm{CH}$ were labeled with $\left[2-{ }^{3} \mathrm{H}\right]$ mannose and Tran ${ }^{35}$ S-label for 60 minutes. The incorporation of $\left[{ }^{3} \mathrm{H}\right]$ mannose into protein was normalized to protein content or to ${ }^{35} \mathrm{~S}$ incorporation. Both methods gave similar results. The patients with CDG consistently showed an approximately 2 -fold higher incorporation of ${ }^{3} \mathrm{H}$ than the control (data not shown).

Endoglycosidase $\mathrm{H}$ (Endo $\mathrm{H}$ ) digestion can indicate the size of an LLO, as Endo $\mathrm{H}$ cleaves protein-bound chains derived from Man M-9 LLO, but not those derived from $\mathrm{Man}_{5}$. Subsequent normal processing of $\mathrm{Man}_{9}$ chains yields an Endo $\mathrm{H}$-sensitive $\mathrm{Man}_{5}$ isomer. Under these labeling conditions, little oligosaccharide processing occurs, and newly synthesized chains are mostly Endo $\mathrm{H}$ sensitive $(17,18)$. In contrast, oligosaccharides from patient $\mathrm{PY}$ and $\mathrm{CH}$ cells were mostly Endo $\mathrm{H}$ resistant (Table 2). Adding $250 \mu \mathrm{M}$ mannose to the culture medium did not significantly affect Endo $\mathrm{H}$ sensitivity of control, but it increased the proportion of Endo $\mathrm{H}$-sensitive oligosaccharides in both PY and $\mathrm{CH}$. Not all patients with CDG make Endo H-resistant chains, however, as a patient with CDG-Ic who is defective in LLO glucosylation (S. Kim, V. Westphal, and H.H. Freeze, unpublished study) has normal Endo H sensitivity (Table 2).

Analysis of LLO. The patients were suspected of synthesizing a truncated LLO precursor. To determine this, LLO was isolated from control and patient cells incubated in glucose-containing medium or in the same 

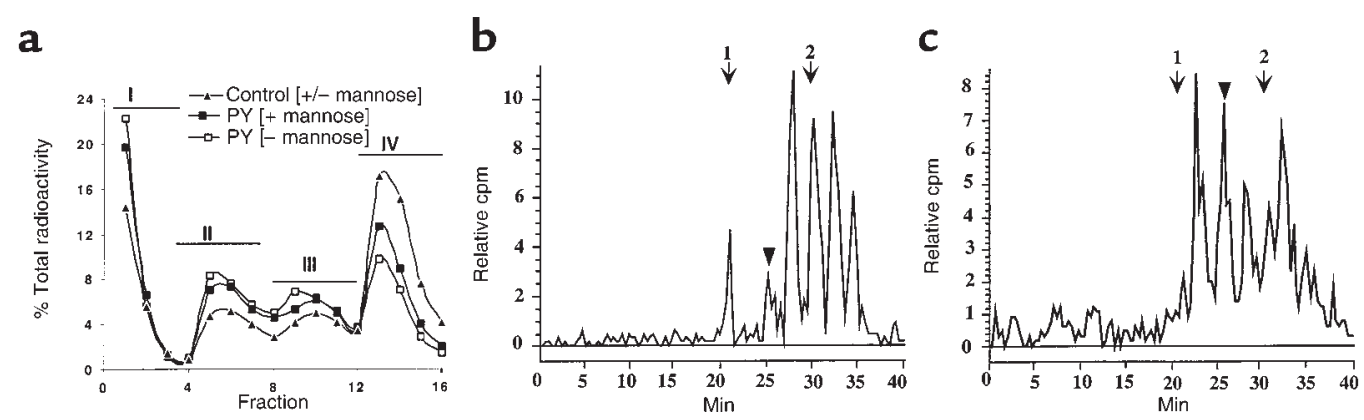

\begin{abstract}
Figure 2
Analysis of $\left[2-{ }^{3} \mathrm{H}\right]$ mannose-labeled oligosaccharides. (a) Con A-Sepharose analysis of PY oligosaccharides labeled with $\left[2-{ }^{3} \mathrm{H}\right] \mathrm{mannose}$ with (filled squares) or without (open squares) a $250 \mathrm{mM}$ mannose supplement as described in Methods. The control profiles with and without mannose were superimposable, and only 1 (filled triangles) is shown. Results are percentage of the total counts recovered. Oligosaccharides from fraction III of control (b) and patient (c) labeled without mannose supplement were mixed with fluorescent 2-

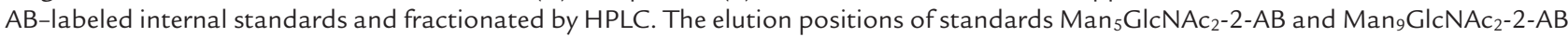
( 1 and 2, respectively) are indicated by the arrows. 2-AB-labeled standards elute earlier than the corresponding free oligosaccharides. Arrowheads indicate position of $\left[2-{ }^{3} \mathrm{H}\right] \mathrm{Man}_{5} \mathrm{GlcNAc}_{2}$
\end{abstract}

medium supplemented with $250 \mu \mathrm{M}$ mannose. In comparison to known standards, the control cells accumulated $\mathrm{Glc}_{3} \mathrm{Man}_{9} \mathrm{GlcNAc}_{2}$, whereas the patients with CDG accumulated primarily $\mathrm{Man}_{5} \mathrm{GlcNAc}_{2}$ along with a small and variable amount of normal-sized chain (Figure 3), suggesting that the patients with CDG have a lesion in LLO synthesis. Adding $250 \mu \mathrm{M}$ mannose eliminated $\mathrm{Man}_{5} \mathrm{GlcNAc}_{2}$ and greatly increased the proportion of normal-sized LLO. This finding probably accounts for the increase in the proportion of Endo $\mathrm{H}$-sensitive oligosaccharides (Table 2) and the higher proportion of label in ConA fraction IV when mannose was present.

Patients are deficient in Dol-P-Man synthase. Dol-P-Man is needed to convert a Man ${ }_{5} \mathrm{GlcNAc}_{2}$ LLO into a Man ${ }_{9} \mathrm{Glc}$ $\mathrm{NAc}_{2}$ LLO. We detected small amounts of Dol-P-[2$\left.{ }^{3} \mathrm{H}\right]$ Man during metabolic labeling of $\mathrm{PY}$ and $\mathrm{CH}$ fibroblasts, but meaningful quantitation is difficult because the patients showed a greater incorporation of label when normalized to protein. In vitro assay of Dol-P-Man synthase activity from control and patients was linear using 2-30 $\mu \mathrm{g}$ microsomal protein and required addition of exogenous Dol-P (data not shown). Microsomes from fibroblasts of PY and $\mathrm{CH}$ had less than 5\% normal activity when assayed under standard conditions (Figure 4a). PY leukocytes and lymphoblasts were also Dol-PMan synthase deficient (data not shown), whereas a patient with CDG-Ic had normal Dol-P-Man synthase activity. All patients had normal Dol-P-Glc synthase activity (data not shown).

The apparent $\mathrm{K}_{\mathrm{m}}$ for GDP-Man in the patients and controls was calculated from several kinetic equations (Figure $4 \mathrm{~b}$ ). The average $\mathrm{K}_{\mathrm{m}}$ for both patients is approximately 6 times higher than for controls, suggesting that mannose supplementation of the intact cells may normalize LLO synthesis by increasing the GDP-Man concentration at the site of Dol-P-Man synthesis. The apparent $\mathrm{K}_{\mathrm{m}}$ for Dol-P $(\sim 145 \mu \mathrm{M})$ was unchanged in the CDG patients. Based on these results, the loss of Dol-P-Man synthase activity could explain the altered
LLO synthesis in both patients.

Analysis of DPM1, DPM2, DPM3, and SL35. Dol-P-Man synthesis in mammalian cells requires at least 3 proteins, Dpm1p, Dpm2p, and Dpm3p, that form a complex. Dpm1p is the catalytic subunit (19). Dpm2p is essential for endoplasmic reticulum (ER) localization and appears to bind Dol-P (20). Dpm3p directly stabilizes the complex by binding to both of the other subunits (21). Reduced Dol-P-Man synthesis could involve defects in DPM1, DPM2, or DPM3. Therefore, we sequenced the coding regions of each gene using the products obtained from RT-PCR with RNA purified from fibroblasts. The coding sequence of DPM1 cDNA from control cells was identical to the published sequence (19). However, patient $\mathrm{CH}$ contained a $\mathrm{C}_{274} \mathrm{G}$ substitution that resulted in an $\mathrm{R}_{92} \mathrm{G}$ replacement. This apparently occurred in both alleles, as there was no evidence of a normal base at this position. PY has the same substitution, but we also

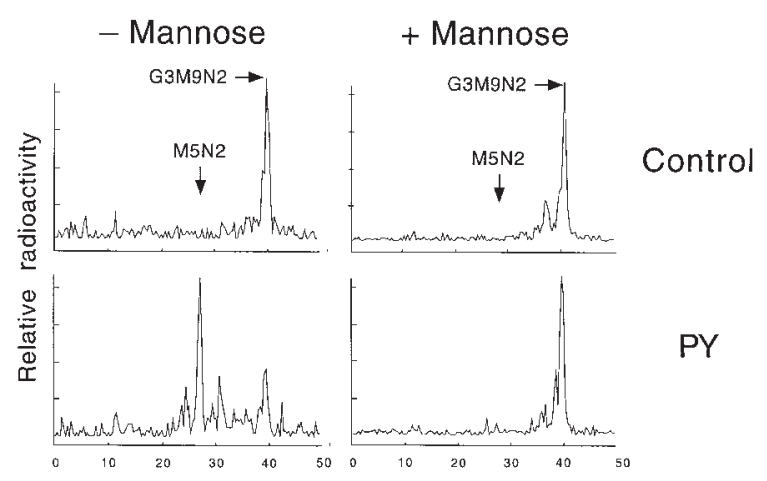

Figure 3

Exogenous mannose corrects the size of LLO from patient PY. Cells from control or patient PY were labeled for 1 hour with $\left[2-{ }^{3} \mathrm{H}\right]$ mannose in medium containing $0.5 \mathrm{mM}$ glucose or $0.5 \mathrm{mM}$ glucose supplemented with $250 \mathrm{mM}$ mannose. The LLO was isolated, hydrolyzed from the lipid, and analyzed by HPLC to separate the oligosaccharides based on their size. Arrows indicate the elution positions of [2$\left.{ }^{3} \mathrm{H}\right] \mathrm{Man}_{5} \mathrm{GlcNA}_{2}(\mathrm{M} 5 \mathrm{~N} 2)$ and $\mathrm{Glc}_{3}\left[2-{ }^{3} \mathrm{H}\right] \mathrm{Man}_{5} \mathrm{GlcNAc}_{2}$ (G3M9N2). 
a

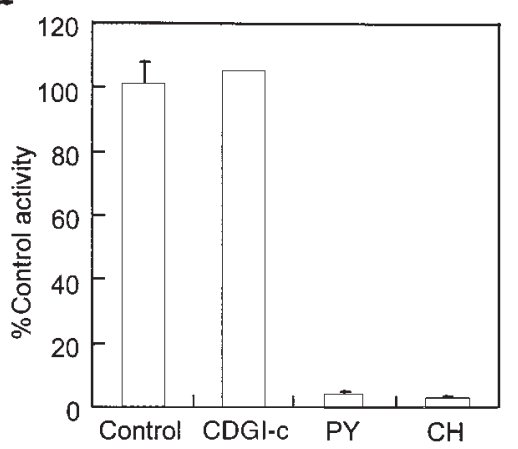

b

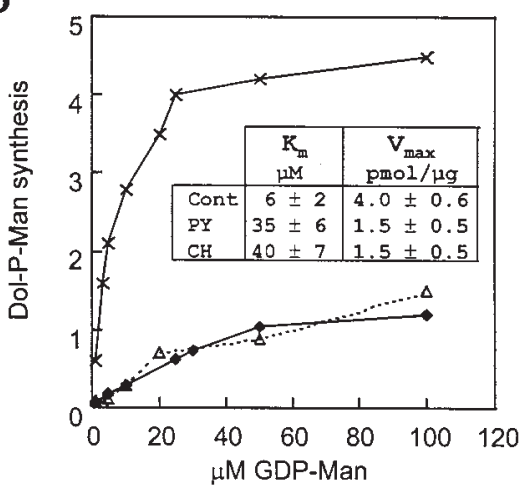

Figure 4

Dol-P-Man synthase activities. (a) Activity of control, CDG-Ic patient, $\mathrm{PY}$, and $\mathrm{CH}$. (b) Dol-P-Man synthesized from control (x), $\mathrm{CH}$ (open triangles), and PY (filled diamonds) as a function of GDP-Man concentration. Insert shows the calculated apparent $\mathrm{K}_{\mathrm{m}}$ and $\mathrm{V}_{\text {max }}$.

detected the normal $\mathrm{C}$ at this position, suggesting that only 1 allele carried this mutation.

The genomic sequence of DPM1 in PY shows a 13-bp deletion in exon 4 resulting in $\Delta 331-343$ on the cDNA level. The predicted translated product would encode the first 110 amino acids of the 260 amino acid protein followed by 44 random amino acids. $\mathrm{CH}$ did not have this deletion in DPM1. The 13-bp deletion was not obvious when sequencing RT-PCR products made from fibroblast RNA, suggesting that this mRNA may be unstable. DPM1 cDNA obtained from semiquantitative RT-PCR was less abundant than the product obtained from healthy control cells (Figure 5), indicat-

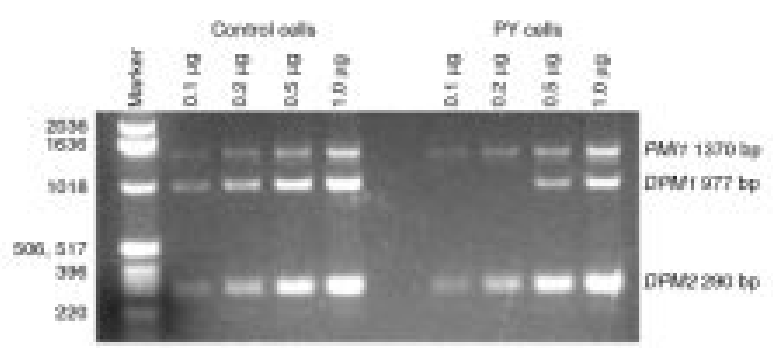

Figure 5

Semiquantitative RT-PCR from total fibroblast RNA. Five microliters of the products from each RNA concentration were loaded on a $1.5 \%$ agarose gel and viewed with ethidium bromide. Reaction conditions are described in Methods. ing that the DPM1 mRNA from PY may be transcribed less efficiently or is unstable compared with normal DPM1 mRNA. This was not seen for DPM2 or PMI1, where essentially the same amounts of mRNA are found in both PY and control cells (Figure 5).

The sequence of DPM2 revealed that $\mathrm{PY}$ and $\mathrm{CH}$ are heterozygous for a $\mathrm{T}_{213} \mathrm{C}$ substitution that is probably a polymorphism, as both codons specify a tyrosine residue. Both patients also have a heterozygous $\mathrm{C}_{227} \mathrm{G}$ that causes a $\mathrm{T}_{76} \mathrm{~S}$ substitution. This alteration in DPM2 was also found in 1 of 2 normal controls and 7 of 8 CDG patients who have defects in PMI, PMM, or $\alpha-1,3$ glucosyl transferase. The high frequency of $T_{76} S$ in this small population suggests that it may be a frequent allelic polymorphism. Sequencing of DPM3 showed the same sequence in 2 control and in both PY and $\mathrm{CH}$. Two assumed polymorphisms were found in all 4 cell lines $\left(\mathrm{C}_{267} \mathrm{G}\right.$ and $\left.\mathrm{G}_{268} \mathrm{C}\right)$. The first does not change the amino acid, but the second results in $\mathrm{V}_{90} \mathrm{~L}$.

SL35 is a gene involved in controlling the utilization, but not the synthesis, of Dol-P-Man $(22,23)$. We found no changes in the primary sequence of the cDNA compared with controls; however, sequencing revealed conflicts with the published sequence for human SL35 (NP_004861). A G $\rightarrow$ T at position 197 causes an $\mathrm{R}_{66} \mathrm{~L}$ substitution, and a $\mathrm{T} \rightarrow \mathrm{C}$ at position 541 results in $\mathrm{Y}_{181} \mathrm{H}$. These changes result in the same sequence reported for the corresponding positions in hamster SL35 (AAD30976).

On the basis of the analysis of all 4 genes known to be involved in the synthesis and utilization of Dol-P-Man, we conclude that mutations in DPM1 are the most likely explanation for the glycosylation defects seen in these patients and fibroblasts derived from them.

\section{Discussion}

A Dol-P-Man synthase deficiency is consistent with the formation of a truncated LLO having 5 mannose residues, as Dol-P-Man is required for further extension of the LLO (24). Although Dol-P-Man synthase activity was very low in an in vitro assay, the loss of activity is not complete, as we detected a small amount of normal-sized LLO (Figure 4) and Dol-P-Man by labeling cells with $\left[2-{ }^{3} \mathrm{H}\right]$ mannose.

Loss of Dol-P-Man synthase activity could result from mutations in several gene products (19-23). Lymphoma ThyE- (25) and CHO Lec15 (26) are both deficient in Dol-P-Man synthase activity (24), but ThyEcarries a mutation in DPM1, whereas Lec15 has a defect in DPM2 $(19,20)$. The human and mouse DPM1 genes share significant homology and 30\% identity with their Saccharomyces cerevisiae counterpart, DPM1 (19). However, the yeast gene encodes a protein with a hydrophobic transmembrane domain that localizes the protein to the ER, whereas the human and mouse genes do not have a transmembrane domain. ER retention is probably mediated by interaction with the noncatalytic subunit, DPM2 (19). This gene may have a regulatory function for Dol-P-Man synthesis and appears to bind 
Dol-P (20). DPM3 is a newly discovered member of the Dol-P-Man synthase complex that encodes a 92 amino acid transmembrane protein that directly binds the other subunits, stabilizing the complex (21).

We found the same point mutation $\left(\mathrm{C}_{274} \mathrm{G}\right)$ in DPM1 in $\mathrm{PY}$ and $\mathrm{CH}$ causing an $\mathrm{R} \rightarrow \mathrm{G}$ change. The arginine is conserved in Mus musculus (BAA25759), Schizosaccharomyces pombe (AAC98795) and Cricetulus griseus (AAD30975), and apparently important for catalytic activity. In addition to this point mutation, PY has a 13-bp deletion that is only detected using genomic DNA as a template. This probably means that the deletion creates an unstable transcript that is degraded. In support of this, we found that the level of DPM1 mRNA in PY was decreased compared with normal levels of PMI1 and DPM2 in this patient. It is not clear why we were able to detect apparent heterozygosity at the $\mathrm{C}_{274} \mathrm{G}$ of $\mathrm{PY}$, given that the transcript carrying the 13-bp deletion would appear to render the mRNA unstable. Because both patients share the same point mutation $\left(\mathrm{R}_{92} \mathrm{G}\right)$, this offers an explanation of why they have the same reduced enzymatic activity, altered apparent $K_{m}$ for GDP-Man, and similar LLO size. Analysis of DPM2 in both patients showed that they are heterozygous for a base substitution, $\mathrm{T}_{213} \mathrm{C}$, which does not alter coding sequence, and are also heterozygous for $\mathrm{C}_{227} \mathrm{G}$, which results in $\mathrm{T}_{76} \mathrm{~S}$ substitution. These alterations may be polymorphisms, as rat and mouse DPM2 have serine at the corresponding position (19). We also sequenced the coding region of $S L 35$, as this gene product appears to be important for the utilization, but not for the synthesis of Dol-P-Man (22, 23 ). We did not find any changes in the patients compared with controls; however, we found 2 positions that differed from the published sequence $\left(\mathrm{G}_{197} \mathrm{~T}\right.$ and $\mathrm{T}_{541} \mathrm{C}$ ). Both changes result in amino acid substitutions. Other yet unidentified genes may regulate Dol$\mathrm{P}-\mathrm{Man}$ synthesis/utilization at 1 or more points in transcription, translation, or post-translational formation of protein complexes.

A Dol-P-Man deficiency may affect several other glycosylation pathways besides $N$-linked oligosaccharide biosynthesis, as Dol-P-Man is required for making glycophospholipid anchors $(19,20)$, C-mannosylated proteins $(27,28)$, and possibly for O-mannose-based oligosaccharides that are found primarily in neural tissues $(29,30)$. At this point, we cannot assess whether a deficiency in any of these pathways contributes to the patients' pathology. However, glycosylation defects specifically limited to the $N$-linked oligosaccharide biosynthesis, e.g., the loss of $\alpha 1,3$ glucosyltransferase activity $(31)$ in CDG-Ic $(32,33)$ are reported to have a less severe pathology than PMM-deficient patients who may be affected in multiple pathways.

Addition of $250 \mu \mathrm{M}$ mannose to the culture medium appeared to normalize LLO synthesis and partially normalize ConA-Sepharose profiles. These results suggest that mannose increases Dol-P-Man synthase activity. One explanation of this is that mannose increases the
GDP-Man pools and the substrate available for the lowaffinity enzyme (Figure 4). This does not necessarily mean that mannose increases the total cellular GDPMan pool, as it would only need to change the effective concentration on the 2-dimensional platform of the ER membrane. We do not know whether the total GDPMan pool is available to Dol-P-Man synthase.

The rationale for adding mannose to the medium is based on earlier observations that mannose normalized LLO synthesis in PMM-deficient patients $(17,18)$. This encouraged clinical studies using mannose as a therapeutic agent. To date, mannose therapy for PMM-deficient patients has not produced positive clinical or biochemical results (34-37). In contrast, mannose has been quite successful in treating patients with PMI deficiency $(6,38,39)$. Patient PY has taken daily mannose supplements for 6 months. Before taking mannose, his age-adjusted weight was consistently below the fifth percentile, despite caloric supplementation. He has now achieved the fifth percentile, but we cannot be certain that mannose caused his weight gain.

\section{Acknowledgments}

This work was supported by NIH grants RO1 GM55695 and DK55615 and the Susan J. Epply Endowment for Pediatric Intensive Care Research and Education to H.H. Freeze. V. Westphal is supported by a postdoctoral fellowship (980029/20) from the Carlsberg Foundation. S. Kim was partly supported by a fellowship from the Korea Science and Engineering Foundation. M.C. Patterson was partly supported by a CR20 award from Mayo Foundation. We gratefully acknowledge the excellent technical assistance of V. Abraham, the expert advice of K. Panneerselvam and Y. Miura, and the generous assistance of E. Schollen and G. Matthijs in the molecular analysis. We thank T. Kinoshita for providing sequence information of human DPM2 and DPM3, and A. Varki for critical reading of the manuscript.

1. Freeze, H.H. 1998. Disorders in protein glycosylation and potential therapy: tip of an iceberg? J. Pediatr. 133:593-600.

2. Krasnewich, D., and Gahl, W.A. 1997. Carbohydrate-deficient glycoprotein syndrome. Adv. Pediatr. 44:109-140.

3. Jaeken, J., Stibler, H., and Hagberg, B. 1991. The carbohydrate-deficient glycoprotein syndrome. A new inherited multisystemic disease with severe nervous system involvement. Acta Paediatr. Scand. Suppl. 375:1-71.

4. Matthijs, G., et al. 1997. Mutations in PMM2, a phosphomannomutase gene on chromosome $16 \mathrm{p} 13$, in carbohydrate-deficient glycoprotein type I syndrome. Nat. Genet. 16:88-92.

5. Van Schaftingen, E., and Jaeken, J. 1995. Phosphomannomutase deficiency is a cause of carbohydrate-deficient glycoprotein syndrome type I. FEBS Lett. 377:318-320.

6. Niehues, R., et al. 1998. Carbohydrate-deficient glycoprotein syndrome type Ib. Phosphomannose isomerase deficiency and mannose therapy.J. Clin. Invest. 101:1414-1420.

7. de Koning, T.J., et al. 1998. A novel disorder of N-glycosylation due to phosphomannose isomerase deficiency. Biochem. Biophys. Res. Commun. 245:38-42.

8. Jaeken, J., et al. 1998. Phosphomannose isomerase deficiency: a carbohydrate-deficient glycoprotein syndrome with hepatic-intestinal presentation. Am. J. Hum. Genet. 62:1535-1539.

9. Stibler, H., Holzbach, U., and Kristiansson, B. 1998. Isoforms and levels of transferrin, antithrombin, alpha(1)-antitrypsin and thyroxine-binding globulin in 48 patients with carbohydrate-deficient glycoprotein syndrome type I. Scand. J. Clin. Lab. Invest. 58:55-61.

10. Coddeville, B., Carchon, H., Jaeken, J., Briand, G., and Spik, G. 1998. Determination of glycan structures and molecular masses of the glyco- 
variants of serum transferrin from a patient with carbohydrate deficient glycoprotein syndrome type II. Glycoconj. J. 15:265-273.

11. Yamashita, K., Ohkura, T., Ideo, H., Ohno, K., and Kanai, M. 1993. Electrospray ionization-mass spectrometric analysis of serum transferrin isoforms in patients with carbohydrate-deficient glycoprotein syndrome. J. Biochem. (Tokyo). 114:766-769.

12. Yamashita, K., et al. 1993. Sugar chains of serum transferrin from patients with carbohydrate deficient glycoprotein syndrome. Evidence of asparagine-N-linked oligosaccharide transfer deficiency. J. Biol. Chem. 268:5783-5789.

13. Wada, Y., et al. 1992. Structure of serum transferrin in carbohydratedeficient glycoprotein syndrome. Biochem. Biophys. Res. Commun. 189:832-836.

14. Harrison, H.H., Miller, K.L., Harbison, M.D., and Slonim, A.E. 1992 Multiple serum protein abnormalities in carbohydrate-deficient glycoprotein syndrome: pathognomonic finding of two-dimensional electrophoresis? Clin. Chem. 38:1390-1392.

15. Stibler, H., Stephani, U., and Kutsch, U. 1995. Carbohydrate-deficient glycoprotein syndrome: a fourth subtype. Neuropediatrics. 26:235-237.

16. Boyum, A. 1974. Separation of blood leucocytes, granulocytes and lymphocytes. Tissue Antigens. 4:269-274

17. Panneerselvam, K., Etchison, J.R., Skovby, F., and Freeze, H.H. 1997. Abnormal metabolism of mannose in families with carbohydrate-deficient glycoprotein syndrome type 1. Biochem. Mol. Med. 61:161-167.

18. Panneerselvam, K., and Freeze, H.H. 1996. Mannose corrects altered Nglycosylation in carbohydrate-deficient glycoprotein syndrome fibroblasts. J. Clin. Invest. 97:1478-1487.

19. Tomita, S., et al. 1998. A homologue of Saccharomyces cerevisiae Dpm1p is not sufficient for synthesis of dolichol-phosphate-mannose in mammalian cells. J. Biol. Chem. 273:9249-9254.

20. Maeda, Y., Tomita, S., Watanabe, R., Ohishi, K., and Kinoshita, T. 1998. $D P M 2$ regulates biosynthesis of dolichol phosphate-mannose in mammalian cells: correct subcellular localization and stabilization of DPM1, and binding of dolichol phosphate. EMBO J. 17:4920-4929.

21. Kinoshita, T., Satoshi, T., Jun, H., Kenji, K., and Yusuke, M. 1999. Human dolichol-phosphate-mannose synthase consists of three subunits, DPM1, DPM2 and DPM3. Glycobiology. 9:1104. (Abstr.)

22. Ware, F.E., and Lehrman, M.A. 1996. Expression cloning of a novel suppressor of the Lec15 and Lec35 glycosylation mutations of Chinese hamster ovary cells. J. Biol. Chem. 271:13935-13938.

23. Ware, F.E., and Lehrman, M.A. 1998. Additions and corrections to expression cloning of a novel suppressor of the Lec15 and Lec35 glycosylation mutations of Chinese hamster ovary cells. J. Biol. Chem. 273:13366.

24. Kornfeld, R., and Kornfeld, S. 1985. Assembly of asparagine-linked oligosaccharides. Annu. Rev. Biochem. 54:631-664.

25. Chapman, A., Fujimoto, K., and Kornfeld, S. 1980. The primary glyco- sylation defect in class E Thy-1-negative mutant mouse lymphoma cells is an inability to synthesize dolichol-P-mannose. J. Biol. Chem. 255:4441-4446.

26. Stoll, J., Robbins, A.R., and Krag, S.S. 1982. Mutant of Chinese hamster ovary cells with altered mannose 6-phosphate receptor activity is unable to synthesize mannosylphosphoryldolichol. Proc. Natl. Acad. Sci. USA. 79: 2296-2300.

27. Krieg, J., et al. 1998. Recognition signal for C-mannosylation of TRP-7 in RNase 2 consists of sequence TRP-X-X-TRP. Mol. Biol. Cell. 9:301-309.

28. Krieg, J., et al. 1997. C-Mannosylation of human RNase 2 is an intracellular process performed by a variety of cultured cells. J. Biol. Chem. 272:26687-26692.

29. Chiba, A., et al. 1997. Structures of sialylated O-linked oligosaccharides of bovine peripheral nerve alpha-dystroglycan. The role of a novel Omannosyl-type oligosaccharide in the binding of alpha-dystroglycan with laminin. J. Biol. Chem. 272:2156-2162.

30. Yuen, C.T., et al. 1997. Brain contains HNK-1 immunoreactive O-glycans of the sulfoglucuronyl lactosamine series that terminate in 2 linked or 2,6-linked hexose (mannose). J. Biol. Chem. 272:8924-8931.

31. Imbach, T., et al. 1999. A mutation in the human ortholog of the Saccharomyces cerevisiae ALG6 gene causes carbohydrate-deficient glycoprotein syndrome type-Ic. Proc. Natl. Acad. Sci. USA. 96:6982-6987.

32. Burda, P., et al. 1998. A novel carbohydrate-deficient glycoprotein syndrome characterized by a deficiency in glucosylation of the dolichollinked oligosaccharide. J. Clin. Invest. 102:647-652.

33. Korner, C., et al. 1998. Carbohydrate-deficient glycoprotein syndrome type V: deficiency of dolichyl-P-Glc:Man9GlcNAc2-PP-dolichyl glucosyltransferase. Proc. Natl. Acad. Sci. USA. 95:13200-13205.

34. Mayatepek, E., Schroder, M., Kohlmuller, D., Bieger, W.P., and Nutzenadel, W. 1997. Continuous mannose infusion in carbohydratedeficient glycoprotein syndrome type I. Acta Paediatr. 86:1138-1140.

35. Marquardt, T., et al. 1997. Mannose therapy in carbohydrate-deficient glycoprotein syndrome type 1: first results from the German multicenter study. Amino Acids. 12:389.

36. Kjaergaard, S., et al. 1998. Failure of short-term mannose therapy of patients with carbohydrate-deficient glycoprotein syndrome type $1 \mathrm{~A}$. Acta. Paediatr. 87:884-888.

37. Mayatepek, E., and Kohlmuller, D. 1998. Mannose supplementation in carbohydrate-deficient glycoprotein syndrome type I and phosphomannomutase deficiency. Eur. J. Pediatr. 157:605-606.

38. de Lonlay, P., et al. 1999. Hyperinsulinemic hypoglycemia as a presenting sign in phosphomannose isomerase deficiency: a new manifestation of carbohydrate-deficient glycoprotein syndrome treatable with mannose. J. Pediatr. 135:379-383.

39. Babovic-Vuksanovic, D., et al. 1999. Severe hypoglycemia as a presenting symptom of carbohydrate-deficient glycoprotein syndrome. J. Pediatr. 135:775-781. 